\title{
The Relationship Between Place Attachment and Color Application at Upnormal Cafe in Bandung Titihan Sarihati ${ }^{1}$, Fajarsani Retno Palupi ${ }^{2}$ and AfiahSafiatunnajah ${ }^{3}$ \\ ${ }^{12} 3$ Interior Design Department, FacultyofCreative Industries, Telkom University, Indonesia 1titiansarihati@telkomuniversity.ac.id, ${ }^{2}$ fajarsanirp@telkomuniversity.ac.id
}

\begin{abstract}
Restaurants and cafes in addition to being a culinary facility, are also used for socialization and relaxation through the presence of a comfortable and attractive space atmosphere. The atmosphere is formed by physical and non-physical factors that simultaneously influence each other in shaping the comfort of visitors. This study seeks to examine the role of interior color elements in contributing to creating atmosphere and place attachments at Upnormal Bandung. This research is an analytical study and uses data collection methods used are a combination of qualitative and quantitative methods to obtain measurable data related to activities and space requirements. The analysis produced in the research in the Cafe Up Normal restaurant shows that the majority of respondents expressed their liking for the restaurant and felt comfortable with the atmosphere of the space. Color and composition are stated to contribute to the attachment to space.
\end{abstract}

Keywords: Color application, cafe, place attachment

\section{INTRODUCTION}

The lifestyle of urban communities, shifting habits of basic needs for food and drink into a lifestyle that is added to other needs, such as socializing, relaxing and the desire to experience other atmosphere that is recreational in a restaurant. Related to this, the atmosphere of space is formed by physical factors and non-physical factors, both of which influence each other. The emergence of various restaurant concepts offered is one of the efforts to achieve interior success in attracting visitors and producing place attachments in a space. Physical factors in the café consist of space-scoping elements which have characteristics such as ornamentation, shape of space, color, material and lighting. While the non-physical aspects that contribute to building the atmosphere are relations between space users and the service system. With the fulfillment of both aspects, the atmosphere of the space will be fulfilled in total.

The existence of restaurants and cafes in the city of Bandung has grown in the last decade. One of the potential and famous cafés in Bandung is Upnormal. Besides being a culinary service provider, the café is also used as a gathering place for work and office work. Upnormal Café in Bandung has a high level of visitor visits so it is quite crowded.

In the initial observations made at Upnormal café, it was found that with a variety of different types of activities and the relatively large number of visitors, visitors at this café did not feel disturbed and stayed long enough in the room or in other words experienced kebetahan in the room. The elements of the atmosphere formed by the interior elements in previous studies prove the role of the visual interior elements to contribute to forming place attachment[1]. 
In order to create interior atmosphere, there are five principles that form the main form of the interior atmosphere, namely: settings, props, special effects, light and shadow, and the last is color. The role of color in this case does not stop at the general color scheme, but also includes graphics and patterns formed in interior design [2]. Specifically in this study, researchers focus on the application of color to the four elements that make up interior space that have been described previously.

\section{METHOD}

This study is an analytical study of the elements forming place attachment in restaurants associated with the application of color in space.Data collection through observation was carried out to see the application of color elements in the café which was then presented descriptively. Data about place attachment in the room obtained through questionnaires and focus group discussions. The questionnaire was prepared with specific parameters abstracted from the findings of a previous study entitled "The Review of Place Attachment on the Interior Atmosphere of Sundanese Restaurants in Bandung". These parameters are then discussed in more depth in the conditioned focus group discussions, also in accordance with the results of previous studies.

This research uses descriptive method that examines the status of a group of people, an object, a system of thought, a set of conditions, or a class of events in the current period. Descriptive research is a research method used to find the broadest possible knowledge of the object of research at any given time[3]

In a previous study found that visitors feel an attachmentin restaurants that have a Sundanese atmosphere, in this case the Sundanese Pavillions restaurant. In addition it was found that the element of kebetahan occurs due to the interior elements. This research will be tested to what extent color elements are able to form kebetahan especially because it is known that color is a visual stimulus that has the greatest contribution in shaping visual perception.

\section{RESULT AND DISCUSSION}

\subsection{Analysis of the Application of Color in Upnormal Cafes}

A person's psychology can be indirectly controlled by the application of the colors used so that it can bring up a different atmosphere. The application of color elements in a room also aims to create an atmosphere of space that is a differentiator in a café. Café Up Normal applies the dominant color to brown which can be psychologically associated with firmness and comfort. Upnormal has a color scheme that is quite typical and is applied in all branches as the identity of Upnormal café itself.

Analysis of the application of color in a normal cafe is described as follows:

\subsubsection{Application of Color to walls, floors, ceilings and openings}

a. Floor

There are two patterns in applying floor colors which can be seen from the image below. On the red wall, the floor is chosen as a dark color derived from concrete slab tile, while when the floor is light or gray the floor is chosen as a bright color. 

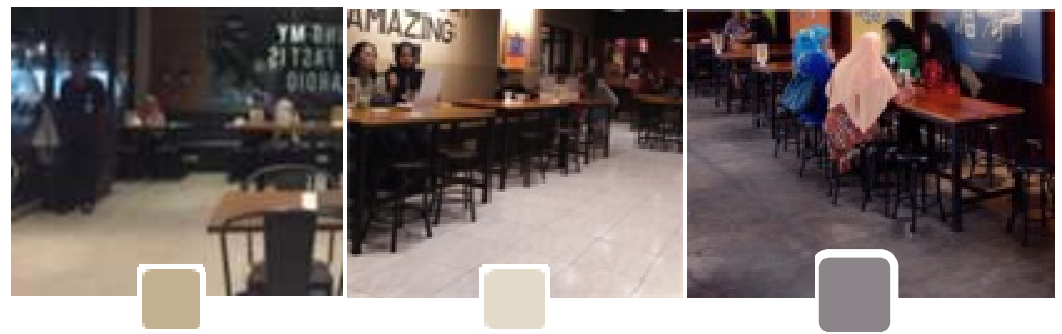

Figure 1. Up-normal floor area 1-left and 2- outdoor area Source: author's documentation, 2019

The followingspectrumof wall colors are used according to the authors observation are :

KhakisRGB (r,g,b) : (195, 176, 145), BonesRGB (r,g,b) : (227, 218, 201),Dim GraysRGB (r,g,b) : (139, $133,137)$

In the picture on the left, the floor color selection is aligned with the wall color. Whereas in the middle picture the color of the floor uses carrara motif ceramic which is quite contrasting with the wall. In the right picture using concrete slab tile as the floor material when most of the walls are red.

b. Wall

The wall has two color application patterns, the first is an exposed brick which is next to a solid color and the second application is a solid color that matches the ceiling.

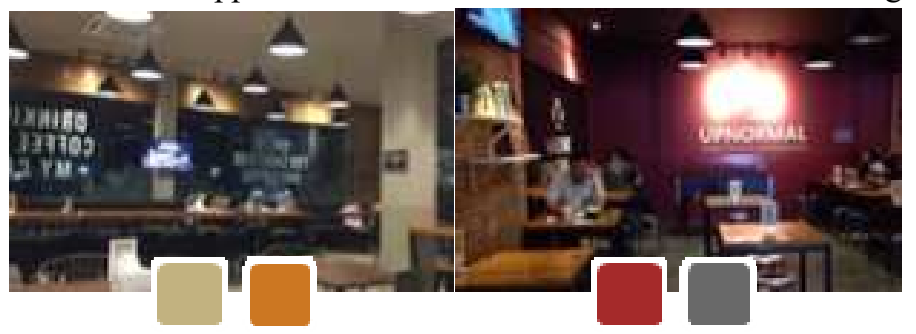

Figure 2. Wall in Upnormal

Source: author'sdocumentation, 2019

The followingspectrumof wall colors are used according totheauthorsobservation are :SandsRGB (r,g,b) : (194, 178, 128),OchresRGB (r,g,b) : (204, 119, 34), AuburnsRGB (r,g,b) : (165, 42, 42), Dim GraysRGB (r,g,b) : $(105,105,105)$

c. Palette

The color of the ceiling that is applied in each of the majority areas is the same as the solid color of the walls of the area, except for the smoking area at the UpnormalBurangrang cafe which partly uses different materials. 


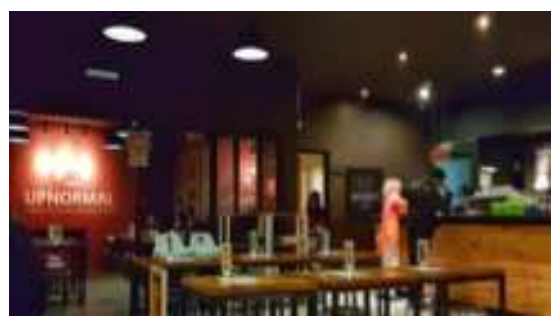

Figure 3 Burangrang Upnormal Ceiling (indoor areas 1 and 2)

Source: author's documentation, 2019

\subsubsection{Color combinations}

Upnormal Cafe uses four kinds of color combinations, each represented by a different interior element. Analysis of color combinations at Upnormal Cafes is described as follows:

a. Combination of Analog and Monochromatic
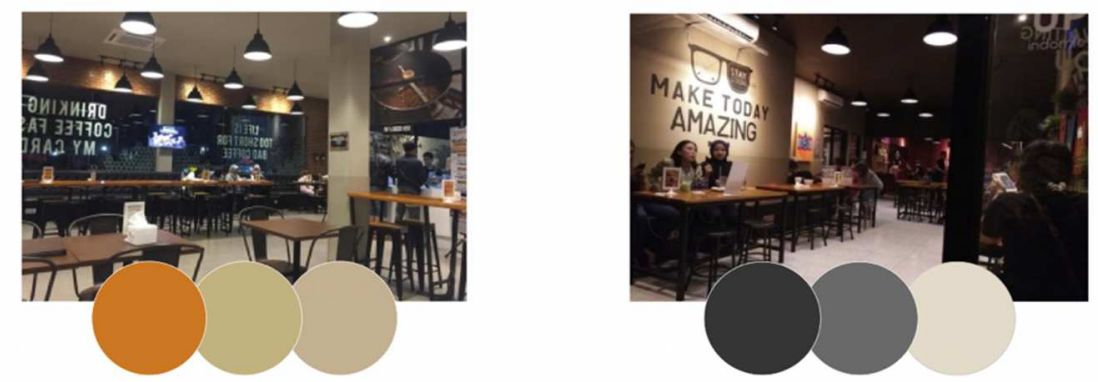

Figure 4 (left) Analog combination. Color ocher on exposed brick walls, sand on columns and ceilings, khaki on the floor.

Figure 5 (right) Interior monochromatic combination (indoor area 1). Jet black color on the lamp armature, sills, doors, windows, and furniture frame. Dim gray on the walls and ceiling, bone on the floor.

b. Branched Complementary Combinations
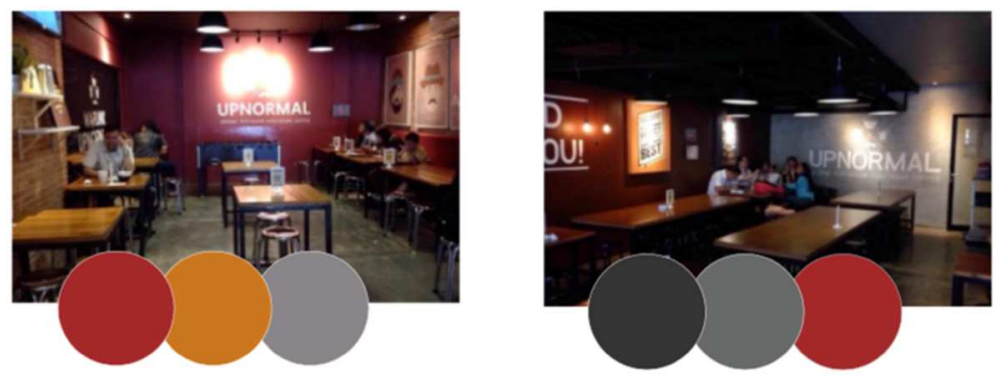

Figure 6 (left) Complementary interior combination of UpnormalBurangrang (indoor area 2). The color of auburn and ocher on the walls and ceiling, the color of Taupe gray on the floor.

Figure 7 (left) Complementary interior combination of UpnormalBurangrang (smoking area). Jet black on the ceiling and furniture frame, auburn and dim gray on the walls. 


\section{c. Complex Combination}

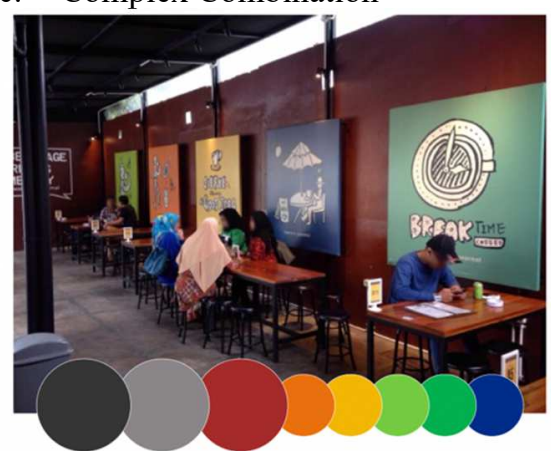

Figure 8Color Combination of UpnormalBurangrang (smoking area) complex. Jet black color on the ceiling and furniture frame, taupe gray color on the floor, auburn color on the wall. While the five other minor colors are represented by images

\subsection{Analysis of Visitor Resentment at Upnormal Café}

To find out the effect of interior settings, especially the use of color in upnormal cafes affect visitor, researchers conducted questionnaires to several respondents. The questions are divided into three parts, the first part is a general question about identity, while the second to the last part is a question that leads to the preference, functional and application of the color of the café.

\subsubsection{Analyzing the Characteristics of Respondents}

To analyze the response aspect of visitor at Upnormal café. Researchers distributed questionnaires to 41 respondents aged 16-30 years consisting of 25 male sexes, and 16 female sexes. The age of most respondents at the age of $21-25$ years as many as $49 \%$ are classified as early adulthood, who are in a stage of warm, close and communicative relationships with or not involving sexual contact. At that age it is possible to have good sense abilities in perceiving space and in good social conditions.

Furthermore, respondents were given a questionnaire related to the motivation of his presence at the Upnormal café. The data obtained showed that the majority of about $39.10 \%$ came for hangout purposes and $34.4 \%$ for work assignments, the rest aimed for eating and drinking activities, dating and business.

\subsubsection{Analysingthe Visitor Resistant Response due to the application of color to interior elements}

From the results of the research conducted, it was found that the majority of $70.7 \%$ agreed that the purpose of visiting the Upnormal Café was due to good service and space facilities. In addition, the majority of respondents as much as $62.6 \%$ expressed strongly agree that the atmosphere of Café Upnormal supports them in their activities, and $90 \%$ feel safe and comfortable when doing activities at Café Upnormal.

The relationship between color combinations in Upnormal cafes is recognized by the majority of respondents as much as $75 \%$ agree that it supports activities more effectively or comfortably. Respondents also stated that the application of color in Upnormal cafes improves a happy, cheerful, and active mood. This is evidenced by the majority of respondents' answers by $75 \%$ agree. So it was ensured that most visitors agreed that the application of colors in upnormal had a good role in shaping the positive mood of café visitors. The follow up 
questions related to color combinations in Café Upnormal helped reduce stress while working or studying, as evidenced by the respondents who answered agreeing to 21 (51.2\%) people.

From the items questions about affection or factors related to emotions and feelings, it is known that the majority of respondents are in a happy condition and a feeling of relaxation also expresses a liking for the restaurant and feels secure peace over its presence in the restaurant, in addition there is a desire to linger when at the restaurant. From these results it can be concluded that the space at the Up Normal café is capable of arousing positive feelings associated with kebetahan. Items of questions about feeling happy, relaxed (comfortable), peaceful, liking the environment or atmosphere as well as lingering desires were approved as feelings caused by their presence in space. Color also plays a role in shaping the comfort and place attachment.

\section{CONCLUSION}

From the analysis produced in the research at the Cafe Up Normal restaurant, there are several results regarding the effect of applying color to the visitor's kebetahan during activities. In the research that has been done it was found that the UpNormal Café applies intense color to all elements of the room, such as analog and monochrome colors. The aspect of cognition is a factor related to memory or memory that is the 'knowledge' that the respondent has. UpNormal Café is able to be a different space experience and pleasant impression formed by intense color applications. The resulting experience is deposited into memory because of its own unique value.

While from the aspect of Behavior or behavior as a reaction that can be produced as a result of the stimuli that are presented. In relation to spatial, these aspects can be related to spatial behavior. Respondents stated that the majority would choose the position of dealing with their partners as the most favorable conditions in a restaurant.It is known that the majority of respondents are in a happy and comfortable condition, and also expressed a liking for the restaurant and feel secure for its presence in the restaurant, besides that there is a desire to linger while in the restaurant. Therefore, it can be conclude that there is a link between the application of color and a sense of comfort felt by restaurant visitors.

\section{REFERENCES}

[1]. T. Sarihati, Pribadi Widodo, danWidiharjo. Penerapan Elemen-elemen Interior sebagai Pembentuk Suasana Ruang Etnik Jawa Pada Restoran Boemi Joglo. Atrat, Vol. 3, No. 3, 2008-222, 2015.

[2]. J. Whitehead, Creating Interior Atmosphere : Mise en Scene and Interior Design, United Kingdom : Bloomsbury Publishing Plc. 2018

[3]. Syah, Hidayat.Pengantar Umum Metodologi Penelitian Pendidikan Pendekatan Verivikatif. Pekanbaru : Suska Pres.2010

[4]. N. Rebecca Noel, Color Psychology Secrets For Interior Design. Published by R.N Resources. 2013

[5]. R. Meldarianda, and H. Lisan, Pengaruh Store Atmosphere Terhadap Minat Beli Konsumen pada Resort Café Atmosphere Bandung. Jurnal Bisnis dan Ekonomi (JBE), Vol.17, No. 2, pp. 97-108.2010

[6]. A. Malekshahi, Investigation on Restaurant Layout Design. Thesis. Eastern Mediterranean University February Gazimağusa, North Cyprus. 2013.

[7]. Brown B, Altman I, Werner C. Place attachment. International Encyclopedia of Housing and Home, pp. 183-188 Published by Elsevier. 2012 
[8]. Deng X, Hui S, Hutchinson J. Consumer preferences for color combinations: An empirical analysis of similarity-based color relationships. Journal of Consumer Psychology, vol. 20, issue 4 pp. 476-484. 2010

[9]. Giuliani M. Theory of attachment and place attachment. Psychological Theories for Environmental Issues, pp. 137-170 Published by Taylor and Francis. 2017

[10]. S. Cho, Restaurant In Types: Contemporary Interior Design And Theory Study. Thesis. Faculty of the Graduate School of Cornell University. 2009.

[11]. W. Tantanatewin W, Inkarojrit V. The influence of emotional response to interior color on restaurant entry decision. International Journal of Hospitality Management, vol. 69,pp. 124-131 Published by Elsevier Ltd. 2018 